\title{
A hybrid Common Redstart x Black Redstart (Phoenicurus phoenicurus $x$ P. ochruros) breeding in southeastern Sweden
}

\author{
En hybrid rödstjärt $x$ svart rödstjärt (Phoenicurus phoenicurus $x$ P. ochruros) \\ häckande i sydöstra Sverige
}

ANNCHARLOTTE PETERSSON, ADAM BERGNER \& MATS THORIN

\begin{abstract}
Breeding Redstart hybrids occur regularly and have been described from central but not from northern Europe. Many of the hybrids exhibit plumages resembling those of eastern subspecies of Black Redstart, making it difficult to assess the identity of certain birds. We present information on a well documented breeding by a hybrid male Common Redstart $\times$ Black Redstart (Phoenicurus phoenicurus $\times$ P. ochruros), successfully rearing offspring together with Common Redstart females at an industrial estate in southeastern Sweden $\left(57^{\circ} 49^{\prime} 16^{\prime \prime} \mathrm{N}\right.$; $15^{\circ} 16$ '52' $\mathrm{E}$ ) in the summers of 2009-2012. During its first summer at the location, the bird was captured and ringed, representing the second Redstart hybrid ever to be ringed in Sweden. With vocals like Black Redstart, the bird had a plumage highly similar to that of indi-

viduals belonging to the subspecies phoenicuroides in central Asia. Examined in hand, the bird exhibited some plumage characters and morphological traits consistent with details previously presented for Redstart hybrids in Europe. We confirm previous assumptions that Redstart hybrids can be separated from similarly looking eastern subspecies of Black Redstarts by means of differences in wing formulae.

AnnCharlotte Petersson, Lagmansryd Karlberg, S-570 61 Ydre, Sweden.E-mail: vadare61@hotmail.com

Adam Bergner, Barnhemsgatan 15, S-582 30 Linköping, Sweden.E-mail: adam.bergner@yahoo.se

Mats Thorin, Skogsgatan 83, S-578 32 Aneby, Sweden. E-mail: thorinaneby@gmail.com
\end{abstract}

Received 17 March 2014, Accepted 30 March 2014, Editor: S. Svensson

\section{Introduction}

Hybridization between the two redstart species Common Redstart Phoenicurus phoenicurus and Black Redstart $P$. ochruros occurs regularly (Grosch 2003, Ertan 2006), and successful breedings between hybrids and their non-hybrid partners have been studied and described in urban environments across Central Europe (see Landmann 1987, Blattner \& Kestenholz 1993, Lambert 1997, Nowak 1999, Grosch 2004, Zedler 2004, Forschler 2006). Since F1-hybrids are known to be fertile and capable of producing viable and fertile progeny through backcrossing (Berthold 1999), individuals exhibiting a broad variation of intermediate traits might occur. Phenotypically, F1-hybrids and backcrosses sometimes also strongly resemble a few subspecies of $P$. ochruros distributed in Asia and the Middle East, particularly semirufus (distributed across the eastern Mediterranean region from Turkish Anatolia southwards to Egypt and eastwards to Syria), ochruros (distributed over much of Turkey, Caucasus region and northern Iran), rufiventris (distrib- uted from Turkmenistan through Pamir eastwards to Himalaya) and phoenicuroides (distributed from Central Asia east to Mongolia) (Cramp 1988, Svensson et al. 2009). In cases of possible records of easterly subspecies of Black Redstarts, hybrids first need to be safely ruled out. During the autumn of 2011, northwestern Europe in general and southern Sweden in particular, was affected by an influx of Black Redstarts exhibiting plumage characters consistent with those of either P. o. phoenicuroides/ ochruros/semirufus/rufiventris, indicating eastern origin. Mitochondrial DNA from one captured individual in Sweden, and one in Great Britain, respectively, revealed strong resemblance to genetic material from Black Redstarts previously collected near the border between Russia and Mongolia (Lagerqvist 2013). Most other birds occurring in Sweden were thoroughly documented with good photos, and due to their relative resemblance in plumage they were all considered as being pure Black Redstarts of eastern or south-eastern origin, from either of the subspecies phoenicuroides/ 
ochruros/semirufus/rufiventris (although, probably mistakenly, published as semirufus/rufiventris/xerophilus in Strid \& Eriksson (2013)). The findings however raised issues on how to safely distinguish between hybrids and eastern subspecies, pointing out large gaps in knowledge about the abundance, distribution and appearance of Redstart hybrids in northern Europe. Nicolai et al. (1996) claimed that hybrids and eastern subspecies of Black Redstarts are inseparable by means of plumage traits alone. Instead, Steijn (2005) and Pérez-Garcia \& Sallent (2011) suggest that differences in the wing formula present stronger reliability.

Here we present information on a confirmed breeding between a hybrid male between Common and Black Redstart and a female Common Redstart, successfully rearing offspring at an industrial estate in southeastern Sweden in the summers of 2009-2012. During its first summer at the location, the Redstart hybrid was also captured and ringed, representing a remarkably rare event in Sweden. We present interesting details on plumage traits and morphological measurements sampled in the hybrid in order to increase the knowledge on individual variation amongst Redstart hybrids in northern Europe.

\section{Record details and biometry methods}

On June 16, 2009, A P visited the timber sale Träullit, located at a small industrial estate in the village of Österbymo, southeastern Sweden (5749'16'N; $\left.15^{\circ} 16^{\prime} 52^{\prime \prime} \mathrm{E}\right)$. The location has previously been known as one of few in this part of the county that annually holds a pair of breeding Black Redstarts. A singing male was found at the location after just a few minutes, but A P concluded that the bird had a plumage deviant from that of the western subspecies $P$. o. gibraltariensis and more resembled that of a Black Redstart of eastern origin, particularly subspecies semirufus and phoenicurioides. A few photos were taken and uploaded on the website forum for bird identification, Swedish Ornithological Society (www.sofnet.org). Some comments were obtained, confirming that the bird was interesting due to its resemblance of eastern subspecies. The comments also pointed out the difficulties in safely distinguish hybrids from eastern subspecies of $P$. ochruros. In order to find out the origin of the bird, AP and local ringer MT visited the location a few times in the end of June, trying to catch the bird. Using two mist-nets and playback of contact calls from both Common Redstart and Black Redstart they eventually managed to capture and ring the bird. Full biometry, including maximum wing length, weight and fat score was taken in the hybrid. Wing formula was assessed using a technique previously described by Svensson (1992).

The male hybrid was breeding together with a female Common Redstart, regularly feeding chicks under the roof ridge of one of the buildings. Three nestlings, estimated to be around two weeks of age, were later ringed. The following springs of 2010 , 2011 and 2012, the male hybrid returned and successfully reared offspring together with female Common Redstarts (own observations).

\section{Results}

\section{Morphology}

The male hybrid strongly resembled a male $P$. $o$. phoenicuroides owing to dark grey back and wings, some white feathers on central forehead and a black throat extending downwards ending in a bow across the central part of the breast (Figure 1-3). The black color also extended to a small area under the carpal joint. Some other characters were found to be intermediate between the two redstart species. The bird was safely determined a hybrid by means of the five following characters: (1) Remaining white color on emargination of outer web on innermost tertial; (2) Paler red color on lower breast and underparts; (3) Scattered white feathers on lower belly (behind the legs), rump and under tail coverts; (4) Absence of emargination of outer web on the sixth primary; and (5) Wingtip was made up of primaries 3-5. Due to extensive abrasion of tips of flight feathers, the exact distances

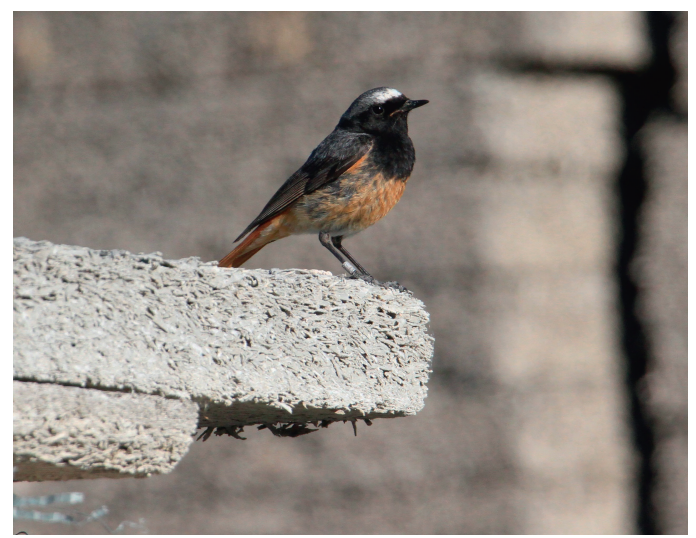

Figure 1. The male hybrid at its breeding site in Österbymo, southeastern Sweden.

Hybridhanen på sin häckningsplats $i$ Österbymo, sydöstra Sverige. Photo: Magnus Johansson. 


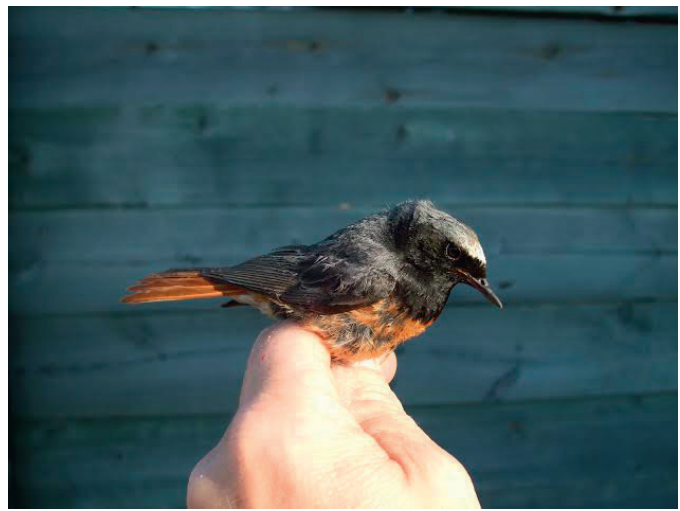

Figure 2. The hybrid male in the hand. Notice the white feathers on central forehead, absence of white margins on outer webs of tertials and secondaries and the extent of black on throat and upper belly, details more or less intermediate between the two Redstart species, but resemble those found in some eastern subspecies of Black Redstart.

Hybridhanen $i$ handen. Notera vita fjädrar $i$ pannan, avsaknad av vita ytterkanter på tertialer och armpennor samt utbredningen av det svarta på strupe och bröst, detaljer som uppvisar mer eller mindre intermediära drag för de båda rödstjärtsarterna, men som påminner om dräkten hos vissa ostliga underarter av svart rödstjärt. Photo: Mats Thorin.

between primary $5 / 6$ and $6 / 7$, respectively, could not be safely determined. The relative distance between the abraded tips was found to be $1: 1$.

\section{Aging and moulting}

Wing- and tail feathers were rather worn, particularly primaries 4-9 (ascendently numbered) with partly or entirely abraded tips. The hybrid exhibited uniformly colored greater coverts and no distinct dark markings on tips of outer tail feathers, equal to that described for adult Black Redstart by Svensson (1992). It was therefore considered an adult bird being two years or older (in its third calendar year or later). During the following three summers (2010-2012), a ringed hybrid male was spotted at the same location. During the first two years, we were unable to tell if it was the original male or just one of the returning juveniles from the summer of 2009. In the summer of 2012, it was eventually confirmed as being the original ringed male owing to photographs where the ring number was successfully read. In the summer of 2012 the age of the male was at least five years, which seems to be a new age record for redstart hybrids in Europe.

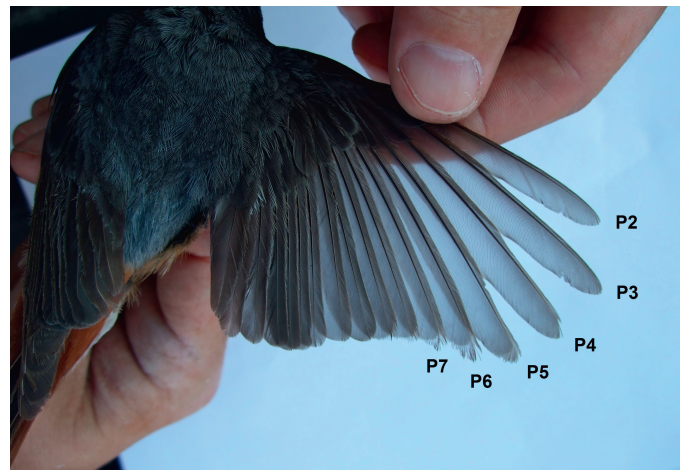

Figure 3. Examination of the hybrid wing. Notice the abraded tips of primaries 4-9. The look of the wing formula resembles that of a Common Redstart with rather low relative distances between the tips of primaries 5-7.

Vingen hos hybridhanen examineras. Notera slitna toppar på handpennorna 4-9. Vingformelns utseende liknar mer den hos rödstjärt med små relativa avstånd mellan topparna hos handpennorna 5-7. Photo: Mats Thorin.

\section{Calls}

The song was inseparable from that of a Black Redstart, while the contact calls resembled those of a Common Redstart. During the attempts to capture the hybrid, contact calls from both Common Redstart and Black Redstart were played in order to catch the bird's attention and attract it towards the mist nets. The bird was obviously enticed to the calls of both recordings, but seemed even more interested in the ones from Common Redstart.

\section{Discussion}

\section{Habitat selection}

In their most natural breeding habitats, the likelihood of hybridization between Common Redstart and Black Redstart has to be considered relatively low due to differences in the species' habitat preferences. Common Redstarts prefer forested areas and parklands, while Black Redstarts are found in mainly tree-less stony and rocky terrain, as well as close to human settlements in villages, industrial estates and harbors (Cramp 1988, Svensson et al. 2009). In urban environments, particularly in areas made up of a mixture of buildings and trees, the two species can be found breeding side by side exhibiting regular interspecific aggression (Sedláček et al. 2004). At the breeding site for the hybrid in Österbymo, Common Redstarts and Black Redstarts can be found breeding in the same environment, which is a mixture of industrial buildings in proximity to open pine forests. 
Recent studies on hybridization between Common Redstart and Black Redstart have shown that plumage characters alone are insufficient for safe determinations of hybrids due to relatively large phenotypical overlap between hybrids and eastern subspecies of $P$. ochruros (Nicolai et al. 1996). According to Steijn (2005) and Pérez-Garcia \& Sallent (2011), details in the wing formula, especially the relative distances between primaries $5 / 6$ and $6 / 7$, respectively, can be used as a relatively safe measure to separate hybrids from eastern subspecies of Black Redstart (Table 1). In Common Redstarts of the nominate form phoenicurus, the relative distances vary from 1:0.41-1:1.17 and in Black Redstarts of the subspecies gibraltariensis from 1:2.0-1:2.5. Individuals of the central-Asian subspecies phoenicuriodes vary from 1:1.57-1:3.0, and show some overlap to hybrids previously examined across Europe (1:0.94-1:2.14). Ertan (2002) found, in his study on hybrids from Germany, the average relative distances to be 1:1.22, significantly less than the lower limit of eastern subspecies of Black Redstarts. That would indicate that hybrids exhibit wing formulae more closely related to the ones found in Common Redstart, and the biometrics of the male hybrid captured in Österbymo fall well into this pattern.

\section{Calls}

Frauendorf et al. (1997) documented hybrids to sing like Black Redstarts, similar to what we found in Österbymo (Petersson 2010). Other observations from Sweden indicate that hybrids occasionally sing like a mixture between the two species, or sometimes like one of the species interspersed with vocals reminding of the other species. In Österby- mo, the hybrid had contact calls resembling those of Common Redstart, but reacted to playback of contact calls from both species.

\section{Redstart hybridization in Sweden}

The abundance of hybridization between the two species of Redstarts naturally occurring in Sweden is not yet well-documented and seems to be a relatively rare event. The first confirmed hybridizations between the two species in Sweden were reported from Skövde, south-central Sweden, in 1959-1960 (Andersson 1963) and Dals Ed, southwestern Sweden, in 1985 (Orrhult 1986). The first confirmed hybrid bird, safely determined by wing formula biometrics and plumage traits, was spotted in the Gothenburg harbor in 1987 (Andersson 1988). Since the mid 1990s, at least ten findings of male hybrids have been reported from Sweden, mainly in the southern parts (The Species Gateway; R. Andersson, pers. comm.). Apart from the confirmed breedings in Österbymo in the summers of 2009-2012, two other hybrid males were observed together with partners during the same period: in the Limhamn limestone quarry, Scania in the spring of 2012 and in the copper mine of Falun, Dalarna in the summer of 2012. In Limhamn, the male hybrid was seen together with a pallid female Redstart (S. Cherrug, pers. comm.), most likely a $P$. phoenicurus. In the copper mine of Falun, the hybrid was observed mating with a female Black Redstart (P. Adenäs, pers. comm.).

Of the Swedish hybrids that have been thoroughly documented with photos, there is a relatively large diversity in plumage traits. A male claiming territory in Västra Tunhem, near Vänersborg, reminded strongly of a male Common Redstart with a slightly grayer tinge on back and head with a black throat extended downwards to the central

Table 1. Wing formula (interval of relative distances between primaries $5 / 6$ and $6 / 7$, respectively) and wing lengths in Common Redstarts, Black Redstarts of subspecies gibraltariensis and phoenicuroides, and hybrids Common Redstart x Black Redstart (according to Pérez-Garcia \& Sallent (2011)) compared with the bird in this study.

Vingformel (intervall för relativa avstånd mellan handpennorna 5/6 och 6/7, respektive) och vinglängd hos hybriden från Österbymo jämfört med mått hos raser av rödstjärt, svart rödstjärt och hybrider.

\begin{tabular}{lcc}
\hline Taxon & Wing formula & Wing-length (mm) \\
& Vingformel & Vinglängd \\
\hline P. p. phoenicurus & $1: 0.41-1: 1.17$ & $77-84$ \\
P. o. gibraltariensis & $1: 2.0-1: 2.5$ & $85-91$ \\
P. o. phoenicuroides & $1: 1.57-1: 3.0$ & $80-85$ \\
P. phoenicurus $x$ P. ochruros & $1: 0.94-1: 2.14$ & $80-85$ \\
Österbymo bird & $1: 1$ & 86 \\
\hline
\end{tabular}


breast (P. Åberg, pers. comm.). Another similar bird was spotted near the copper mine of Falun in the summers of 2011 and 2012, with the exception of having a diffuse white wing panel. A second calendar year male (aged by means of remaining brownish-tinged juvenile flight feathers) temporarily observed near Torslandaviken, Gothenburg in April 2008 resembled a male $P$. ochruros semirufus, but exhibited some white feathers on central forehead and a diffuse transition between black throat and red underparts on upper belly. The male in Limhamn strongly resembled a male Black Redstart, typically exhibiting white wing panels. The black throat extended downwards to the upper belly, ending in a diffuse transition to red underparts. A tricky bird observed and photographed in the harbor of Malmö in 1994 was initially reported as a male P. o. phoenicuroides (see Olsson 1994). A few years later, following an increased knowledge and experience in the subject, the reported bird was, however, re-examined and eventually assessed a probable hybrid, despite the strong resemblance to central-Asian subspecies.

According to photos available in the Species Gateway database, Redstart hybrids spotted in Sweden exhibit a rather broad variation in plumage traits. The relative differences might, however, not be that pronounced as assumed, and too large conclusions should not be drawn since the photos hold some differences in lighting and contrast. Plumage characters that seem to be most varying are the look and extension of black on throat and upper belly, the amount of white feathers/feather tips on central forehead and the presence/absence of whitish outer margins on tertials and secondaries. Large variation in plumage characters can be expected from hybrids in different stages of generations, and shows the difficulties in safely distinguish hybrids from eastern subspecies of $P$. ochruros by means of plumage characters alone.

\section{Acknowledgements}

We thank Magnus Hellström and Magnus Ullman for their initial comments on the bird's appearance, and Reino Andersson for constructive advices that helped to improve the manuscript. Håkan Söderberg assisted during the ringing session and Magnus Johansson kindly let us use one of his photos.

\section{References}

Andersson, G. 1963. Svart rödstjärthane bastarderande med vanlig rödstjärthona i Skövde. Vår Fågelvärld 22: 290 291.

Andersson, R. 1988. Revirhävdande rödstjärthybrid. Vår Fågelvärld 47: 149-150.

Berthold, P. 1999. Towards a comprehensive theory for the evolution, control and adaptability of avian migration. In: Adams, N.J. \& Slotow, R.H. (eds.) Proceedings of the 22:th International Ornithological Congress, Durban. Journal of African Ornithology 70: 1-11.

Blattner, M. \& Kestenholz, M. 1993. Brut eines wahrscheinlichen hybriden Haus x Gartenrotschwanz Phoenicurus ochruros x P. phoenicurus in der Schweiz. Ornitologisches Beobachter 90: 241-245.

Cramp, S. (eds.) 1988. Handbook of the Birds of Europe, the Middle East and North Africa. Vol. 5. Oxford University Press, Oxford, England.

Ertan, K.T. 2002. Evolutionary biology of the genus phoenicurus. Phylogeography, natural hybridization and population dynamics. Tectum Verlag, Marburg.

Ertan, K.T. 2006. The evolutionary history of Eurasian redstarts, Phoenicurus. Acta Zoologica Sinica 52: 310-313.

Forschler, M.I. 2006. Successful broods of a hybrid between redstart Phoenicurus phoenicurus and black redstart Phoenicurus ochruros. Vogelwarte 43: 195.

Frauendorf, E., Günther, H., Schrack, M. \& Ernst, S. 1997. Hybrid zwischen Gartenrotschwanz Phoenicurus phoenicurus und Hausrotschwanz Phoenicurus ochruros mit gesang des Hausrot-schwanzes. Mitt. Ver. Sächs. Orn. 8: 105-109.

Grosch, K. 2003. Hybridization between two insectivorous bird species and the effect on prey-handling efficiency. Evolutionary Ecology 17: 1-17.

Grosch, K. 2004. Hybridization between redstart Phoenicurus phoenicurus and black redstart $P$. ochruros, and the effect on habitat exploitation. Journal of Avian Biology 35: 217-223.

Lagerqvist, M. 2013. DNA-fonden - reder ut genetiken. RoadRunner 21(2): 60-62.

Lambert, M. 1997. Staying and nesting of a hybrid Black Redstart X Common Redstart showing characters of Phoenicurus ochruros phoenicuroides. Aves 34: 32-38.

Landmann, A. 1987. Über bastardierung und mischbruten zwischen Gartenrotschwanz (Phoenicurus phoenicurus) und Hausrotschwanz (P. ochruros). Ökologische Vögel 9: 97-106.

Nicolai, B., Schmidt, C., Schmidt, F.U. 1996. Gefiedermerkmale, masse und alterskennzeichen des Hausrotschwanz (Phoenicurus ochruros). Limicola 10:1-41.

Nowak, M. 1999. Bemerkungen zu mischbruten, hybridisierung, abnormer gefiederfärbung und mischgesang bei Gartenrotschwanz (Phoenicurus phoenicurus) und Hausrotschwanz (Phoenicurus ochruros). Naturkdl. Mitt. Lks. Göppingen 18: 9-15.

Olsson, R. 1994. Svart rödstjärt av östlig ras - den första i Skåne - påträffad i Malmö. Anser 33: 212-214.

Orrhult, S. 1986. Svart rödstjärt - en oväntad fortsättning. Natur på Dal 12: 6-7.

Pérez-Garcia, J.M., Sallent, Á. 2011. Identificación de híbridos en el campo: el caso del anillamiento de un híbrido de Colirrojo tizón (Phoenicurus ochruros) y Colirrojo real (Phoenicurus phoenicurus) en el P. N. del Archipiéla- 
go de Cabrera. Revista de Anillamiento 28: 30-35.

Petersson, AC. 2010. Hybridhäckning i Österbymo 2009. Vingspegeln 29: 2-4.

Sedláček, O., Fuchs, R. \& Exnerová, A. 2004. Redstart (Phoenicurus phoenicurus) and Black Redstart (P. ochruros) in a mosaic urban environment: neighbors or rivals? Journal of Avian Biology 35: 336-343.

Steijn, L.B. 2005. Eastern Black Redstarts at IJmuiden, the Netherlands, and on Guernsey, Channel Islands, in October 2003, and their identification, distribution and taxonomy. Dutch Birding 27: 171-194.

Strid, T., Eriksson, A. (eds.) 2013. Fågelrapport 2012. Fågelåret 2012. SOF. Halmstad.

Svensson, L. 1992. Identification guide to European passerines. Fourth, revised and enlarged edition. Stockholm.

Svensson, L., Mullarney, K. \& Zetterström, D. 2009. Fågelguiden - Europas och Medelhavsområdets fåglar i fält. Andra omarbetade och utökade upplagan. Bonnier Fakta.

Zedler, A. 2004. Hybrider Garten- x Hausrotschwanz füttert Junge. Falke 51: 324-325.

\section{Sammanfattning}

I mitten av juni 2009 upptäcktes en avvikande hanfärgad svart rödstjärt (Figur 1-3) på ett industriområde i samhället Österbymo i södra Östergötland. Fågeln sjöng som en sådan och påminde utseendemässigt starkt om en svart rödstjärt av den centralasiatiska underarten phoenicuroides med bl.a. mörkt grå rygg och vingovansidor, en del vitt i pannan samt en stor svart strupe som slutade $i$ en vid båge centralt över bröstet. Dock utmärkte den sig genom att uppvisa en diffus övergång mellan svart haklapp/bröst och mer blekt rödfärgad mage och undergump med insprängda vita fjädrar. Det är sedan tidigare känt att hybridisering mellan rödstjärt och svart rödstjärt förekommer sällsynt men regelbundet och att såväl första generationens hybrider som återkorsningar är fertila. Hybrider är fenotypiskt variabla och överlappar till viss del utseendemässigt ostliga svarta rödstjärtar, varför säker bestämning med ledning av dräktkaraktärer många gånger är omöjligt. Enligt nyligen publicerat material från Steijn (2005) och Pérez-Garcia \& Sallent (2011) beskrivs istället de relativa avstånden mellan handpennespetsarna $5 / 6$ och 6/7 som en av få utslagsgivande karaktärer. Hybrider har i tyska studier uppvisat en vingformel med ett relativt avstånd om 1:1,22, ett mått intermediärt mellan den europeiska nominatformen av rödstjärt $(1: 0,41-1: 1,17)$ och svart rödstjärt av den västliga underarten $g i$ braltariensis (1:2,0-1:2,29). För att säkert kunna uttala sig om ursprunget beslöts att fånga och ringmärka den östgötska fågeln för att i detalj kunna studera dräktkaraktärer och vingformel. I slutet av juni 2009 lyckades fångstförsöket, och vid samma tillfälle kunde också tre ännu ej flygfärdiga ung- ar, resultatet av en samhäckning mellan den hanfärgade fågeln och en hona av rödstjärt, märkas. Den hanfärgade individen uppvisade jämnfärgade större täckare och teckningar på yttre stjärtpennor liknande de hos adult svart rödstjärt, varför den kunde bokföras som $3 \mathrm{k}+$. Individen kunde sedermera säkert bestämmas till en hybrid mellan den västliga underarten av svart rödstjärt (Phoenicurus ochruros gibraltariensis) och nominatformen av rödstjärt (Phoenicurus phoenicurus phoenicurus) med ledning av följande fem karaktärer: 1) kvarsittande vitt på inre tertialens inre ytterfan, 2) blekare röd färg på kroppsundersidan, 3) vitfärgad nedre buk (bakom benen), undergump och undre stjärttäckare, 4) avsaknad av ytterfansinskärning på sjätte handpennan, och 5) vingspetsen bildades av handpennorna 3-5. Slitna handpennespetsar gav inte möjligheter att exakt fastställa avstånden mellan handpennorna 5/6 och 6/7. Det relativa avståndet mellan de avnötta fjäderskaften var cirka 1:1. Särskilt den senare karaktären är ett relativt starkt indicium för att den hanfärgade individen var en hybrid mellan de båda i Sverige förekommande rödstjärtsarterna (Tabell 1). Den aktuella fågeln återkom till industriområdet också nästföljande tre säsonger och genomförde lyckade häckningar med rödstjärtshonor. Den konstaterades under sommaren 2012 vara en fågel av minst fem års ålder $(6 \mathrm{k}+)$, vilket så vitt känt är ett nytt åldersrekord för rödstjärtshybrider i Europa.

Den första konstaterade hybridiseringen mellan rödstjärt och svart rödstjärt i Sverige konstaterades i de västgötska orterna Skövde 1959-1960 och Dals Ed 1985. Konstaterade eller möjliga häckningar mellan rödstjärtshybrider och sina artrena partners har rapporterats ett tiotal gånger i Sverige det senaste decenniet. Den aktuella fågeln i Österbymo utgjorde emellertid den blott andra ringmärkta hybriden någonsin i Sverige, efter ett förstafynd i Göteborg 1987. Det är dock den enda individ som utvärderats närmare och jämförts med fåglar från den europeiska kontinenten. Bland de misstänkta hybrider som fotograferats i Sverige de senaste femton åren finns en relativt stor variation $i$ fjäderdräkt (med viss reservation för att tillgängliga foton håller olika ljus- och färgmättnad). De tre dräktkaraktärer som tycks vara mest variabla är 1) förekomst/ ickeförekomst av vita tertial- och armpennekanter, 2) mängden vita fjädrar i pannan och 3) utbredningen och utseendet av det svarta på bröstet. Dessa skillnader i utseende kan förväntas bland hybrider av olika generationer, och visar på svårigheterna att säkert kunna särskilja hybrider och ostliga svarta rödstjärtar med ledning av enbart dräktkaraktärer. 